que ad monasterium nostrum spectent hujasmodi sub penâ contra dilapidantes ecclesias et monasteris sua de jare inflictŝ injungimus dicto abbati ut absque more dispendio sufficienter reparet, ant si necesse fuerit reedificet, quoniam timetar ne processu temporis edificia et dormitorium predicta ad tantam argeant ruinam quod facultates et reditus dicti monasterii ad manutencionem eorundem simul cum aliis oneribus non sufficiant.

Injungimus insuper dicto abbati quod omnia hostia ciros clanstrum quam circa ecclesiam nocturnis temporibus horis congruis claudantur, et in auroris apperiantur, et quod non pateat canonicis facultes egrediendi dictum monesterium nostram nisi per portam aut viam communem ducontem ad dictum monasterium, sub pen $\hat{a}$ contemptûs; et quod si vie hujusmodi modo sint, precludentur et obserentur, ut omnis occasio mali inde cenonicis nostris auferatur.

In cujus rei testimonium sigillam nostrum presentibus est appensum. Dat. in hospitio apud vetus Templum London. die Mensis Janii decimo, anno Domini millesimo quingentesimo nono, et nostre consecrationis anno nono.

OROMWEIL AND THE INBURREOTION OF 1655.

\title{
II. The Insurrection.
}

Iv my first article I sketched the history of the royalist conspiracy from which the insurrection of March 1655 arose; in this I propose to give the history of the rising itself, and to conclude my examination of Mr. Palgrave's account of it. As a preliminary, however, I wish to point out the change which has taken place in his position, and the alteration which he has effected in his mode of proof.

In the Quarterly Review article Mr. Palgrave charged Cromwell with 'fabricating' and 'manufacturing' the insurrection. In his three popers in the EnaLish Histonical Review he reduces the charge to mere 'complicity in the insurrection.' '

In the Quarterly article Mr. Palgrave claimed credit for the adoption of ' $a$ method as yet untried ' in dealing with Cromwell.

Instead of attempting a review of Cromwell's whole career, to gain an idea of what manner of man he was, a single train of events in which his hand was visible throughout has been subjected to some degree of soratiny. A man's words and deeds, although arising only on one occesion, may supply an effectual test of his real self.?

In his three replies, however, Mr. Palgrave, instead of confining himself to this 'single train of events,' ranges over the whole field of Cromwell's government, reviews all the plots of the period, from Gerard's plot in 1654 to Hewitt's in 1658, discusses the finances of

I English Hist. Revioro, iii. 621.

Q Quartorly Roviow, cixii. 414. 
the protectorate, and inserts excursus on the characters of Thomas Cromwell and Thomas Carlyle. Into these digressions I do not intend to follow him: I prefer to confine myself to the subject which he originally selected for investigation. The method he proclaims has some defects, as will be shown hereafter. But it has the inestimable advantage of limiting the area of discussion, and rendering a close examination of evidence possible. It has also an additional advantage. According to Mr. Palgrave's own principles of criticism, an exsmination into the value of his account of this one event will supply ' an effectual test' of the value of his other accounts of events of the same nature, and will enable us to determine the value of his historical writings in general.

My former article ended with the despatch of the king's agents to the English royalists, and the arrival of Rochester and Wagstaffe in England in February 1655. According to Mr. Palgrave they landed at Dover, selecting that place because they reckoned on the assistance of the clerk of the passage. On this supposition he builds a theory of Cromwell's complicity in the revolt, which a few pages later becomes a fact of damning importance. ${ }^{3}$ The defect of the argument is that there is good evidence that Rochester and Wagataffe landed at Margate and not at Dover." One of the leaders in the Salisbury insurrection asserts this on the authority of Wagstaffe himself. Mr. Palgrave goes on to describe Rochester and his companion as met at Dover by agents of Cromwell's who gave them false promises of co-operation. The sole evidence on which this statement is based is a bit of royalist gossip circulated in the following summer which does not contain the definite details given by $\mathrm{Mr}$. Palgra.ve. ${ }^{\circ}$

But to retarn to the emissaries of Charles II. and the progress of the grand design. The Earl of Rochester and his companion made their way-safely to London, which they reached about 23 Feb. 1655. Rochester was twice examined on the way, but succoeded in giving a plansible account of himself. In London Sir Thomas Peyton procured him lodgings in the house of a tailor in Aldersgate Street where he stayed till 27 Feb. ${ }^{6}$ Daniel O'Neill who

- Quarterly Review, clxii. 421; English Hist. Roviow, iv. 129. In the former Mr. Palgrave thus describes the landing of the conspirators: "They came, not in a amall party, dropping over one by one, selecting different and out-of-the-way spots for landing, but almost in a body, in quick succossion, they alighted at Dover.'

4 Tharloe, iii. 844.

- 'Cromwell's second appearance on the scene was his sending pretended army mntineers to Dover to encourage Lord Rochester to proceed with his andertaking.' English Hist. Revioro, iii. 523, iv. 121, 126 ; Quarterly Review, clrii. p. 423.

- Calendar Olarerdon Papers, iii. 21, 28; English Hist. Reviow, iii. 8B8, 837; Tharloe, iii. 849. The examinstions of the tailor and his wife taken six weaks later (April B) contain some interesting facts about their lodger: " he was a proper tat man, with a very round visage; he was sheved olose in his face, and the hair upon his head was yellowish, and it might be a periwig for all the examinato knoweth.' He passed by 
had succeoded in escaping from his detention at Dover was already in London, and thus the two plenipotentiaries despatched by the king met again in England. Roohester was charged specially ' to assist and direct' those who had determined on an insurrection. 0 'Neill was 'to beget a right understanding amongst them,' and to induce the Sealed Knot to join the party of action. How he fulfilled his tesk his own letters will best show. ${ }^{7}$

London, 8 Maroh, 165 .

Sir,- After I had received your orders to componnd for your debts, I made all the heste'conveniently I could hither, where I found all your accounts and business in such disorder by the absence of some of your friends, and the restraint of others who are bound for you, and the despair of those you addressed me to, whom I found strong in the same persuasion they writ to you, that Mr. Ambrose (Nicholes Armorer) and I began to think there was no good to be done, and that it was fitter to return to our homes, than spend money when wecould do you no service. Mr. Arvile (Bir Thomas Armstrong) dissuaded me from this resolution, and told me there was great disposition in your creditors to compound, and at an easy rate, if I would take upon me to have your authority, which he believed none would question or desire to see. I told him that would be hazarded, and sent him to assure those he knew of my coming and the power I had. That very day I spoke nnto half a score, who with great cheerfulness offered to take two shillings in the pound rather than you should continue a banished man; bat how to deal with Mr. Hamely ${ }^{8}$ whose consent was most necessary I could not devise, Mr. Wroth (Lord Willoughby), ${ }^{9}$ his friend, being of late, by reason of some differences with those entrusted by you here, not very forward to meddle; anto him I employed Mr. Ambrose (N. Armorer), whom I thonght upon the score of their old friendship would prevail with him. Before he could bring me his answer Clew (Compton) ${ }^{10}$ was sent from his partners to me to tell me they would assist me in all they conld, though they believed little good would be done.

I told him of the disposition I foand those I spoke with, and that I donbted not with their assistance the composition would be moderated, for Blacke (Mr. Booth) would undertake to bring Catting (Cheshire) to reason ; so would Mr. Fowell (Fairfax) honest Mr. Yardford (Yorkshire) his consin, 'and Willings (the West) would be as the rest, and St. Owin (Bhrewsbury) would be as forward as any, and that Mr. Stow (Sr. Robert Bhirley) wonld

the name of Bymonds, and had a French servant with him. This eervant was taken at Aylesbury on Maroh 20, and no doubt revealed his master's Irondon eddress. Thurloe, iii. 281, 8B5.

T These letters are endorsed 'Mr. Bryan's letters to Mr. Jackson of the 8th and 9th of March, old style 1654.' They are to be found in Egorton MSS. 2535, 1f. 74-7. On 26 March, 1655, Ormond wrote to Beoretary Nioholas sammariaing the news con. tained in them. In a later letter of $80 \mathrm{March}$, these papers were enclosed (fi. 102, 103). They are copies in the handwriting, according to Mr. Warner, of Jobn Nicholes.

- Mr. Hamely. This pseudonym is not explained, perheps Lrord Denbigh.

- See Calondar Clarendon Papers, iii. 19.

1- Sir William Compton, a member of the Sealed Knot, who are the partners roferred to. They thus determined to abandon their opposition and throw in their lot with the party of action. 
give good example to all : with this he returned very well satisfied. Bat before I could hear from him again, or Mr. Ambrose (Armorer) bring me the answer of Mr. Wroth (Lord Willoughby), as God would have it Mr. Rothall (Lord Rochester) came to town with your authority which gave such life to the business, that in five days, which was the whole time of his stay here, we brought all your creditors to such a composition as we hope will not displease you. Mr. Willings (the west), Mr. Newet (the north), Mr. Catting (Cheshire) and Mr. St. Owin (Shrewsbury) promised to receive satisfaction on this dey, and the rest soon after. I had almost forgot to tell you that your most faithful servant Knoply (Kent) is not able to serve you for the present; so that the money which he should furnish must be supplied some other where. The reason Knoply (Kent) is so disabled is because most of Mr. Axford's family (the army) lives with him. Mr. Catz (Cromwell) sent them thither hearing that Mr. Kinsford (the king) pretended to be his heir. If you be remembered I did long since tell you that poor man would be made nnserviceable to you, if the resolution I left Kinsford (the king) in were put in execution; a resolution not owned by any of his friends here, now it's past blaming you or him." ${ }^{\text {B }}$ by the post I shell write to you, if I find there be more liberty and safety for letters than there has been since the discovery of the plot; in the mean time, since that you are there do not stir until you hear further from me. Mr. Rothall (Earl Rochester) is gone to Yates (Yorkshire), his own house, he was in such haste to go home, that he could not write to you, which he prays you to pardon him for. He assures me he will secure Mr. Fowell (Lord Fairfax) for any engagement he shall make in your behalf. I must confess Mr. Rothall (Earl Rochester) was the next best you could authorise to deal with your creditors, bat there were many that did not like him, which I prevailed with to make no unreasonable exception; there were others that wondered Mr. Ofeild (Ormond) had not the charge the other had to treat, for he would have been more authentic, and said, too, that if he had been here when he was expected, which was two months ago, in all likelihood you might have been at home with your wife and children now peaceably. But I gave them reasons that satisfed them more then myself; but I hope all is well. Some days before I came to my house at Dopping (Dover) there was Mr. Billing (Duke of Buckingham) came from Fitham (France), there one of Mr. Corf's (Cromwell's) men met him, they stayed sir hours together: I do believe their meeting was not for your advantage. Soon after they parted Mr. Billing (Buckingham) returned from whence he came. The man that makes this good intelligence between them is Mr. Juxley's (Lord Jermyn's) clerk with the red hesd, ${ }^{12}$ you know him, he is a poet, and a malicious enemy of yours. I desire you not to be startled at what all your best friends assure me, and so they have Mr. Rothall (Lord Rochester) too, who prayed me to acquaint you with it, it is that one you trusted very much here, especially in your correspondence with my Lady Bise (Biron), he is Mr. Kilburg's (King's) man, has betrayed all your accounts to Mr. Corf (Cromwell) who opposes

"This refers to the king's removal trom Cologne to Holland.

12 Abraham Cowley is evidently meant; he was Jermyn's secretary and Backingham's triend. He was now in England and was arrested for his share in this plot sbout 16 April 1655 (The Fathful Scout, 18-20 April, 1655). There is no reagon to doubt his fidelity to the king. 
much your return and composition, you are infinitely prejudiced by this as I am informed. I'll not be positive that this is true, bat sure I am that one of the best friends Mr. Corf (Cromwell) hes, assures it your friends. By the skipper that brings you this, if you return the flax and Rhenish wines, it will be well, for the last will be a very good commodity here. Summer is coming on and I am assured the French will not agree with us, now they find we are engaged against the Spaniard in the West Indies. I never expected from that inconstant nation better dealing. Mr. Wroth (Lord Willoughby) presents his services to you, he says Mr. Ward (Sir William Waller) and his partner Mons. Bursett (Major General Browne), will make a good stock to join with you in your proposition; he is gone to Laford (Lincolnshire) to take possession of some land he has bought there. Mr. Rothall (L. Rochester) obliged me to stay here until our business be perfected, which I hope will shortly be, if there be any faith in men. You cannot well send to me because I cannot direct you whither you should send your letters. I beseech God bless you and preserve you. I pray you believe no man is readier to hazard life and fortune for you than,

\section{Yours etc.}

P.S.- Since I writ thus far I have found a way that you may send to me by the post after you receive this, write in your own hand for it's the least known here. I am assured by an express from Newett (the north) that Mr. Fowell (Lord Fairfax) is very hearty in your business. I returned him all the thanks and assurance I could, that he should be no loser. If that be so, as the poet said

\section{If this day thrive we'll ride in coaches, If not bonnes noches. ${ }^{13}$}

Mr. Wroth (Lord Willoughby) would have Mr. Rothall (Lord Roohester) get him some fine diaper (a declaration) he was willing to content him ; I told him he ought to buy none here, and that you had good acquaintance in Holland and his best course would be to leave it to you. It is a commodity much desired here by all sorts, but they have such nonsensical conceits, that there is some impossibility to please their humours. The old fellow ${ }^{14}$ of Eldon (Ely) was here, and returned as positive as ever. Mr. Plume (Bir Thomas Peyton) is one of the discreetest and affectionatest friends I found you have here. He is infinitely troubled at the misfortane of your servant Knoply (Kent), he was with me yester-night, and told me he was not out of hope, to make him yet come off with a considerable sum towards your composition. I pray you let me know what directions you have sent to your factor at Paris and Mr. Youthy (the Duke of York), it were not amiss now that we are ready to break with that country, that you give order they remove from thence your stock, or to leave them at their own liberty, when they shall think fit to remove. It were not amiss if they got liberty for Mr. Jones (the Irish) to lesve the Monsieur, he hath served

10'Neil quotes, or tries to quote, Dr. James 8mith: Mrusarum Dolioia, p. 27, ed. Hotten :

-If this dey amile they'll ride in cosches, And, if it trown, then Bonas Noches.'

14 Probably Bir Miles Hobart; Calendar Clarendon Papers, ii. 845, 356, 869. 
too long there and he will be a most useful servant to you when you come home.

There is one Sadler (Seymour) that was lately with you, that made such indiscreet discourses since his return, that if by good fortane most of your creditors were not compounded with before he came, it's likely they would have kept at a greater distance than they have done. For God's sake beware of such loose tongues until your business be past their spoiling it.

Mr. Thomas who will deliver this to gou will tell you how you may send. If the fat fellow ${ }^{15}$ be with you, I hope he will not complain I write short letters. God bless you.

In a second letter dated London, 9 March, 165告, O'Neill wrote to the king.

Good Cousin,-I did ever believe your impatience would bring more inconvenience upon your business than you would believe. Your coming so near makes all your creditors believe you are so anxious to return that you will give five shillings in the pound, rather than stay abroad one year more, so that those who would take two in the pound demand now five and six, which comes to such a sum, that many of your friends believe they cannot serve you at present; however I hope something will be done if we can get in the monies due to you soon, for most of your creditors want money as well as we, and I am assured if they see ready money they will be brought to their old temper. I have sent Mr. Rothell (Lord Rochester) to Yardford (Yorkshire), Mr. Wroth (Lord Willoughby) to Laford (Lincolnshire), and Blacke (Booth) to Catting (Chester) to call in for your money, and sell the cattle. They all promised to have done their basiness the 8th, which was yesterday, and that I should have news of them to send to you by the next post, you need not doubt of their diligence they being all engaged for you, there is one gone to Willings (the west) and another to St. Owin (Shrewsbury) to dispose of the plate and the hangings, all must be turned into money and little enough. I am assured Mr. Fowell (Lord Fainfax) is very hearty in your business, if so your composition will have little rub, for he hath great credit with most of your creditors. Mr. Catz (Cromwell) Las oppressed your servant Knoply so, that I doubt me it will be a great while before he can pay any money. There is one Sadler (Seymour) ${ }^{16}$ who was lately with you that hath done

1" Hyde. Rebellion, xiv. 67.

14 Henry Seymour was employed by the western roynlists to the king in May 1654. He obtained a pass from Cromwell to France on plen of private business, but secretly communicated with the king, Calondar Clarendon Papers, ii. 358, 359, 861. Rebellion, xiv. 82. Clarendon sugests no doubt of his fidelity. On Seymour's return he was imprisoned (17 Jane), and confessed a good deal. In Egerton MSS. 2584, 1. 234, Lord Hatton describes Cromwell's examination of Eeymonr: 'Cromwell asked him what he had done in France, whether he had seen his Master, and rondered he could think to elude by tho idle pretexts he gave him for his journey and return. Seymour denied the sight of his Master. Cromwell told him when and where he saw him, and in what rooms, and some things that were said, as Seymour doth acknowledge. He persists yet in denial, whereupon Cromwell raised his threats so high that Beymour fell as low as his feet and there lny begging his lifo in much distraction. He was then by Crompell and his secretary examined who elso ho saw in Paris. Beymour acknowledgeth none bat Iord Hatton, being arged who he saw or met there he nemes 
you infinite prejudice since his return hither. He gives out that Mr. Ofeild (Ormond) told him that Hurter had no commission from you to call in your debts, that he is but a mountebank; and none is to deal for your debts but he, he has already hindered $500 l$. which should have been given in to $\mathrm{Mr}$. Hurter, which would stop many a gap now, it may be more than 2,000l. will at another time. I hope you will beware of giving more of those commissions or of employing persons of light humours and tongues. I shall send to his broker and have him order him other ways than he doth himself. ...

These letters prove conclusively the genuine nature of the attempted insurrection of March 1655. They revesl the ceuses which led the royalists to persist in their design even after the discoveries of January and February had destroyed all reasonable prospect of success. The responsibility for the useless bloodshed which that persistence caused falls principally on the king, in that he encouraged the rash offers of the party of action, and did not support the wiser counsels of the Sealed Knot. It must be shared by his agents O'Neill and Rochester, who, with full powers to decide, determined to attempt a hopeless enterprise, and by the leaders of the English cavaliers whose exaggerated promises led to the fatal resolution.

At the very time when O'Neill was writing so hopefully to the king the great design was already a failure. The Yorkshire cavaliers met on the night of Thursday, 8 March, on Marston Moor, but dispersed without striking a blow. 'Their intention was,' writes Thurloe, ' to have surprised York, and they expected for that purpose 4,000 men to have come in to them there, and had with them four cartloads of arms to have armed the men with; but all that the Lord Wilmot, Sir Henry Slingsby, Sir Richard Maleverer, Mr. Hutton, and several other persons could bring into the field with them were scarce one hundred men, which did so discourage them that they flung away their arms and dispersed themselves.' 17

Clarendon exaggerates the importance of this gathering, and lays the blame of failure on Rochester. 'Rochester ... made his way into Yorkshire at the time appointed, and found such an appearance of gentlemen upon the place as might very well have deserved his

Bir E. Hyde, asked if Sir E. H. came frequently to Irord Hatton, he sayes, aye. Asked what talk passed, he says Sir E. H. found lault with the ment and such like railleries. Asked of the intimacy betwirt Sir E. H. and Lord Hatton, he says there was mach, esked what letters or messages Hatton sent by him, he says none, nor knew he any in England that corresponded with Hatton; he wes highly urged and threatened upon that point as Beymour sends Irord Hatton word. He was then sent to a colonel's lodging as a prisoner, which recovered him again, and he was settled again in mind.'

17 Thurloe to Pell, March 16, 1655 . Vaughan, The Protectorate of Oliver Crom. well, i. 147. Other ecconts aro given in Morcurius Politicus, Nos. 248, 249, pp. $6196,5209,5210$. One gives the number of cavaliers as 200 , another as 800 . An eyewitness deposes to seoing the four cartloads of arms brought into York the next day. One acconnt gives Friday night, 8 March, as the date. 
patience. It appeared that there had been some mistake in the notice that had been given, and they who did appear undertook for many who were absent that if he would appoint another short day for the rendezvous he should be well attended. . . . Bat he took many exceptions; complained as if they had deceived him; and asked many questions which were rather reasonable than seasonable, and which could have farnished reasons against entering apon the design, which were not to be arged now when they were to execute, and when indeed they had gone too far to retire.' ${ }^{18}$ Accordingly he refused to appoint a new day, the gentlemen went to their homes, and he started back to London.

Contemporary accounts clear Rochester and attribute the failure to other causes. Captain Peter Mews thus summarises the information he derived from Sir Richard Maleverer and other persons engaged in the plot. 'They all speak very honourably of Earl Rochester, and say he did all that was possible. Mr. Walter Strickland is very much complained on, as one who was the occasion of dissolving the rendezvous in the north, particularly that he met Duke Darcy coming up with fifty horse and stopped them.' 19 Another cause assigned was the absence of Sir Marmaduke Langdale. The northern gentlemen wished to have him to command them. ${ }^{20}$ Langdale's presence 'was promised but not intended, he not being of Hyde's Cabal, which made many fail to come to the rendezvous.' 21 Langdale himself complains of not being employed by the king. ${ }^{22}$ Manning, the spy who professed to derive his information from Sir Richard Maleverer, speaks of the miscondact of Strickland, but lays most stress on the confusion caused by the postponement of the day. This, in itself the most probable reason, is confirmed by Major Robert Walters, another of the leaders of the royalists. Walters said that he had

' three several times been countermanded by the council after he had absolutely appointed the days, and that the deputies of the Bishopric of Durham, Northumberland and the north of Yorkshire had been with him, and had given him an account of their readiness and that he believed so many countermands discouraged them so far that it hindered so general a rising as would have been at first.' 23

Others complained that Fairfax had broken his engagements.

1* Rebellion, riv. 185.

1. Mews to Nicholas, June 4, 1655, Egerton MSS. 2585, L. 239.

- Calendar Clarendon Papors, ii. 888, 400 (?).

1 Calondar State Papers, Dom. 1655, p. 216.

"Egerton MSS. 2595, f1. 109, 122.

Thurloe, ii. 728,

24 A correspondent writes to Nicholas on June 11, 1655 : 'The Duke of Buckingham, as epoken in my presence by a person of quality, says pablicly that the Irord Fairfax promised to engese for his Majesty's interest, provided the transeotions between his Majesty and him might pass through the Duke's hands, which request being refused his 
On the same night of 8 March a number of Nottinghamshire royalists assembled in arms:-

About $\mathbf{8 0 0}$ horse [writes Thurloe] were got together at a place called Rufford, who brought with them a cartload of arms, to arm such others as should come in to them, but finding the country came not in, about twelve o'clock at night, they cried out in a fright they were betrayed, and so shifted every man for himself, leaving the cart to get away as it could, since which our horse have been ranging the conntry thereabouts, and have seized many of the chief of the persons that were present at the meoting. ${ }^{2.5}$

The exact number of the party is uncertain. According to the first account of the intended rising, given in a letter from Nottinghamshire of 17 March, they numbered about five hundred horsemen. This figure, certainly much too high, is adopted in the 'Declaration of the Protector and Council,' published in the following November. In the deposition of Sir George Savile's groom they are said to have been about two hundred. ${ }^{25}$

The chief persons implicated were, Sir George Bavile, afterwards the celebrated earl of Halifax, at an inn near whose house at Rafford the conspirators met. Savile was himself in London, but had provided a quantity of arms and got together thirty-six horses. His steward and the gentlemen of his household were amongst those present at the meeting. Mr., afterwards Sir, William Coventry, Savile's brother-in-law, was actively concerned in the preparations. ${ }^{97}$

Richard, Lord Biron, was also engaged in the business and was to have been leader of the Nottinghamshire gentlemen, but he also was at this time in London. ${ }^{28}$ Amongst those actually present at the meeting were Major Scott, John and Cecil Cooper, sons of Sir Roger Cooper of Thurgarton, late officers in the king's army, Mr. Peniston Whalley of Screceton, Notts, and other gentlemen. These persons had mostly been engaged in the first civil war and in the royalist rising in Nottinghamshire in 1648. Lord Biron also headed a small rising in Nottinghamshire in $1659 . .^{30}$ The

Lordship quitted, and so his Majesty's design was trustratod.' On this Nicholas com. ments that he 'does not know nor can he find that there was ever any promise from the Lord Fairfax that he would engege for his Majesty's interest, so as the transactions between his Majesty and him might pess through the Duke's hands, adding it is said by some that know Lord Fairlax rery well, that he hatb not any intention at all to engage tor the King's interest.' Egerton MSS. 2535, 1. 248. Depositions on the Yorkshire plot are to be found in Thurloe, iii. 226, 840, 248, 288, 386, 392, 399, 530, 723.

2) Vaughan, i. 146.

4 Mercurius Politicus, March 165t, pp. 5195, 5207 ; Declaration, p. 31 ; Tharloe, vii. 302.

"Thurloe, iii. 264, iv. 599, vii. 263, 301.

- Calendar State Papers, Dom. 1655, p. 213 ; Calendar Clarendon Papers, vol. ii. No. 2108 ; Memoirs of Mrs. Hutchinwon, ii. 221, ed. 1885.

$\Rightarrow$ Thurloe, iii. 228, 241, 264, iv. 699, vii. 269, 301.

- Memoirs of Colonel Butehinson, ii. 889. 
depositions assign two causes for the sudden break-up of the meeting at Rufford, firstly the fact that the cavaliers were not joined by so many people as they expected, secondly the receipt of news from York, that the rising there was adjourned or abandoned.

A third meeting of the royalists took place on the same night at Morpeth. ${ }^{31}$ They intended to seize Newcastle and Tynemouth Castle. ${ }^{32}$ The number of persons who met together is estimated at sixty or eighty persons. Four men, three of them eye-witnesses, deposed to the fact of the gathering. They hoped to be joined by other parties from Durham and from the north of Yorkshire. But about midnight bad news came, and they fled like those who had met at Rufford.

Attempts were also planned against the castles of Shrewsbury and Chester, but they were equally abortive. The Deciaration thus refers to them :-

Those in North Wales and Shropshire, part of which were designed to surprise and possess Shrewsbury Town and Castle; some of the chief persons being discovered and apprehended the rest fled. . . . There were other smaller parties as in the Town of Chester who designed the surprise of the Cestle there, and also in Staffordshire; with divers other places in the nation; but they failing in their expectations, were discouraged for that time.

The design against Shrewsbury is mentioned in the correspondence of Clarendon, and in the letter of $O^{\prime} N$ Neill before quoted. Cromwell obtained information of it, and early in March took the necessary measures to prevent it. On 5 March he wrote to Col. William Crowne:-

It being justly apprehended that the Cavalier party intends speedy execution of a very evil design in the parts about Shrewsbury, which they specially intend becsuse of the weakness of the garrison and the number of Malignants thereabouts, I send you down commissions for a regiment which you are to command for protection of the honest party and securing

"Thurloe, iii. 216, 222, 228, 230; Vaughan, i. 148.

$n$ The design to seize Tynemonth and Newcastle is mentioned in Clarendon's correspondence (Calendar Clarendon Papers, ii. 835, 336, 383; Thurloe, ij. 513). Colonel Edward Gray who was to have commanded had been arrested in January, and this helped to canse the failure of the plot. In Morcturius Politicus it is stated that on 15 March ' it was certified by a letter from Newcastle that a party of cavaliers, about 120, had a design this day seven-night to have surprised Newcastle, but understanding that two troops of our horse were new come into the town, they darst not make an attempt but gave it over ' (p. 5211). The declaration attributes the safety of Newcestle to the coming of $\mathbf{3 0 0}$ foot from Berwick ordered thither for the security of that place (p. 30). Troops were certainly sent by Monk from Scotland in December 1654 and March 1655 to reinforce the garrisons in the north of England. One of the deponents asys that the cause of the break-up of the meeting was news ' that $\mathbf{8 0 0}$ sail of ships had come into Newcastle for fear of whom they durst not fall upon Newcastle at that time ' (Thurloe, iii. 223). The canse first assigned seems the more probable.

n Declaration, p. 31 ; Calendar Clarendon Paper., ii. 335, 396, 440 ; ante, p. 818, and English Hist. Reviero, iii. 325. 
of Shrewsbury garrison. You are to repair thither, and advise with your friends about this and other instructions which I have lately given to the governor there, to whom I have lately sent a troop of horse. ${ }^{34}$.

Crowne received the letter on $7 \mathrm{March}$, and immediately raised fifty men amongst his friends. Mackworth, the governor of Shrewsbury, was equally prompt. Learning that the plotters were to meet on the evening of $8 \mathrm{March}$, in the park of Sir Thomas Harris about five miles from Shrewsbury, he determined to seize the leaders before the rendezvous took place. He wrote to the Protector on the morning of $8 \mathrm{March}$ :-

The troop your highness ordered not being come, and the soldiers under my command being too small a number to form a party out of them to desl with the conspirators when they make. their rendezvous, I have ordered the present seizare of 20 horse in this town and to mount on them some soldiers and some confident friends who shall immediately seize upon the persons of Sir Thomas Harries and Kynaston before their party join ; which I hope will dissipate the intended meeting of this party. ${ }^{\text {so }}$

Mackworth's detachment arrested Harries in the midst of his preparations, found twenty horse ready saddled in his stables, thirteen pair of pistols, bullets newly-cast in his study, a barrel of powder in his barn, all evidence of the warlike intentions which he digclaimed. He was brought back a prisoner to Shrewsbury; the same evening the troop arrived from Hereford, and the town was safe against surprise. ${ }^{\circ 6}$ Moreover a certain Ralph Kynaston, who was proved by many witnesses to have attempted to enlist men for the king's service in connexion with this design, turned evidence, confessed the plot, and gave a detailed account of the means intended to have been adopted for surprising the castle. ${ }^{37}$

Other depositions amongst Thurloe's papers spenk of suspicious meetings amongst the cavaliers of Worcestershire and Montgomeryshire, and of a plot to surprise Chester Castle. ${ }^{3 s}$ It was also intended by the royalists that risings should take place at the same time in

4 Catendar State Papers, Dom. 1655, p. 269.

2s Tharloe, iii. 208.

" Mr. Palgrave's trestment of this plot is characteristic of his method. He selocts two or three apparent improbabilities trom Kynaston's confession on the strength of which he denies the reslity of the plot. He overlooks all the rest of the evidence, and 8ays nothing of the hostile preparations of Sir Thomas Harris. He omits to mention the fact that the reality of the design against Shrewsbury is proved by the evidence of the royalist correspondence in the Nicholas and Clarendon Papers; seo English Hist. Reviewo, iii. 325, and ante, pp. 815,318. Colonel Bcriven, the person who in the previous autumn had undertaken to seize Bhrewsbary, was in communication with Harris three days before the intended surprise in March, as Harris himself owned (Thurlne, iii. 286). There Fes also taken, in company with Harris, Mr. Thomas Armstrong, son of Sir Thomas Armstrong, one of O'Neill's chief assistants in laying the design. He had just come from London and was perhaps the messenger whom 0 'Neill mentions as having been despatched to Shrewsbury (ante, p. 818; Thurloe, iii. 216, 285, 286).

2. Thurloe, iii. 209, 210, 217, 218, 226, 252. 
both Lancashire and Cheshire. Lancashire, however, was kept quiet by the landing of the troops which the Protector had sent for from Ireland. Cheshire was full of royalists, and the castle of Chester was small and weakly garrisoned, but the Cheshire cavaliers do not appesr to have done more than to enlist a few men and to reconnoitre the castle. No attack was attempted on $8 \mathrm{March}$, the day which had been fixed for the common rising. The commander of the cavaliers was to have been Col. John Booth, ancle of Sir George Booth who headed the 1659 rising. Lord Rivers, Randal Egerton, Col. Robert Werden, Mr. Ravenscroft and others were concerned in the plot. $\$$ Several of these persons were arrested on suspicion, but no evidence could be procured against them, and they were dismissed after a brief detention. In August, however, a couple of the men who had been employed in the preliminary reconnaissance of the castle made statements which revealed what had occurred and specially implicated Col. Robert Werden. ${ }^{40}$ But, beyond the imposition of the usual decimation tax on their estates, no punishment appears to have been inflicted on the plotters, no doubt because their plot had nover ripened into action.

In the west of England only did the long preparations of the royalists end in actual fighting. In that district there had been established in 1650 a wide-spreading royalist league, known as 'the western association.' ${ }^{41}$ Broken for a time in consequence of the defeat of Worcester, it was revived again in 1654. Unfortunately the death of Lord Beauchamp, the heir of the Marquis of Hertford, in March 1654, had deprived it of its guiding spirit."2 His place was ill supplied by the appointment of one or two gentlemen in every county to head the forces of their neighbourhood." Of these local leaders two of the chief, Sir Humphrey Bennett and Sir John Greenville, and a number of minor personages, were already under arrest. When Rochester was sent to England the king had also despatched a messenger (Trelawney) to call the western royalists to arms, and according to Clarendon their agents met Rochester in London. ${ }^{41}$

- Thurloe, lii. 338, 348, iv. 122.

- Thurloe, iii. 676, 701 ; Calcndar State Pajers, Dom. 1655, 828, 597.

"Calendar Slate Papers, Dom. 1650, pp. 47, 89, 152 ; Niciwolas Papers, p. 178.

- Calendar Clarendon Papers, ii. 381, 850.

- Calendar Clarendon Papers, ii. 850.

14 Rebellion, xiv. 180, 181 ; Calendar Clarctudm Papers, ii. 19. As it is a part of Ar. Palgrave's theory that the messengers sent by the English royalists to the king were traitors, I may as well supply the names of the chiof intermediaries between Charles and the western royalists. They were (1) Henry Beymour, son of Sir Edward Seymour of Berry Pomeroy, on whom Collins's Peerage, ed. Brydges, i. 193 ; the Clarendon and Nicholas Papers, and ante, p. 318. (2) Jonathan Trelswney, son of Sir John Trelnpney, and brother-in-lsw of Henry Seymour; v. Canden Mriscellany, vol. ii. ; Tre. lannory Papers, pp. 11, 13; and Calendar Clarendon Papers, ii. 19. (8) Edward Penruddock, brother of John Penruddock, once a six clerk in the Chancery ( 0 . Thurloe, iii. 315, 459; Calcudar State Papers, Dom. 1600, p. 342). 
These agents, he continues, 'desired no more than that Sir Joseph Wagstaff might be anthorised to be in the head of them, who had been well known to them.' Wagstaffe was a soldier of considerable experience. He hed spent some time in the service of France; in June 1642 was a lieutenant-colonel in the army destined for Ireland, became next lieutenant-colonel of Hampden's regiment, and when taken prisoner in January 1642 changed sides and entered the king's service. He was given a commission to raise a regiment of foot, becaine serjeant major-general of prince Maurice's western army, was knighted at Crediton 27 July 1644, and distinguished himself by his soldierly conduct in the diastrous battle of Langport. Clarendon characterises him as 'a man generally beloved, and though he was rather for execution than counsel, a stout man, who looked not far before him, yet he had a great companionableness in his nature, which exceedingly prevailed with those who, in the intermission of fighting, loved to spend their time in jollity and mirth.' 4 It was this combination of qualities which recommended Wagstaff to Rochester as a companion and to the western royalists as a leader.

The rising in the west took place on Sunday, 11 March, three days after the date fixed for the general insurrection. "They designed,' writes Thurloe, 'to rise at the same time, and to have begun with the judges at Winchester; but being disappointed by the coming of a troop of horse into that town, they deferred their insurrection till the Monday after.' ${ }^{46}$ On Sunday some sixty cavaliers assembled in Clarendon park near Salisbury, Mr. Mompesson brought forty men from that city to join them, and others met them from Dorsetshirn, so, with about two handred followers in all, Wagstaffe and Penruddock entered Salisbury early on the morning of Mondey 12 March.7

Leaving a strong party in the market-place they stationed guards at the doors of all the inns and seized the judges, Rolles and Nicholas, and the sheriff, Colonel John Dove, in their beds. Wagstaffe resolved, after proclaiming the king, to cause all three to be hanged, but the tenderheartedness of the conntry gentlemen and the passionate opposition of Penruddock prevented what Clarendon thinks would have been a seasonable act of severity. ${ }^{48}$ Accordingly they contented themselves with burning the commis-

'3 Clarendon Reballion, xiv. 181 ; Mercurius Aulisus, 6 Jan. 1649 ; Peacook, Army Lists, pp. 46, 70 ; Black, Oxford Docquets, p. 1; Symonds, Diary, p. 2 ; Bulstrode, Momoirs, p. 140; Calendar Clarendon Papers, i. 268, 290.

16 Vaughan, i. 149.

17 An account of the preliminary morenents of the royalists based on the deposi. tions in Thurloe is contained in Hoare's Modem Wiltshire, 'Salisbury,' p. 424 . Sto also Mercurius Politicus, pp. 5195, 5196, and the exanination of Wagstaffe s servant, Arthar Collins, The Weekly Intelligencer, 27 March, 3 April, 16j5. The time of entering Salisbury is variously stated to be either 2 A.N. or 4 A.d.

4. xiv. 183 . 
sions of the judges and left the judges themselves at Salisbury as prisoners on parole. The sheriff, however, was less fortanate; he was obnoxious not merely on account of his office, bat as a great purchaser of forfeited estates, and as one of the hing's judges. His house was successfully defended by Major Wansey and a party of thirty men, and thus saved from plunder. But Dove himself was ill treated for refusing to proclaim Charles II, carried off to serve as a hostage, and not released till the cavaliers reached Yeovil. During their brief occupation of Salisbury they broke open the gaol, and released the prisoners, some of whom joined them. They also seized, in order to mount their new recruits, the horses of the lawyers and the gentlemen who had come to the city to attend the assizes. Then about eight on Monday morning, with their numbers increased to about four hundred, Wagstaffe and his followers marched away into Dorsetshire. At Blandford, Penruddock proclaimed Charles $\Pi$, and declared for the settling of the true protestant religion, for the liberty of the subject, and the privileges of parliament. At Dorchester also the gaol was broken open and the prisoners released. Their route through Dorsetshire is rather difficult to define, for they seem to have divided themselves into several detachments, but they are described as quartering at Shaftesbury and Sherborne on Monday night, and at Yeovil on Tuesday night. ${ }^{9}$ They had expected to be joined by three or four thousand men in Dorsetshire, but only a few score men had joined them..$^{50}$ Of their friends many, such as Bennett, Greenville, and Wyndham, had been already arrested ; others, like the Marquis of Hertford on whom they confidently counted, sat still and made no sign. ${ }^{s 1}$ Instead of declaring for them the country seemed disposed to declare against them.

It is not essy to imagine [wrote Thurloe to Pell] how they think to get through Devonshire, we having some horse there, and the country is already up with great numbers both of horse and foot, as Somersetshire also is; the gentlemen of which connty did in three days raise three thousand men, to have fallen upon them in case they had come through their county towards Bristol, as was first reported they would endeavour to do; and that the gentlemen of Somersetshire did this day signify to the Protector, under their hands, with assurances that they wonld do their nttermost to break them, thinking indeed this party of the Cavaliers had been much more considerable than they proved to be. ${ }^{88}$

- Thurloe, iii. 243, 246, 248; Morcurius Politicus, p.5196; Veughan, Protectorate of Oliver Cromwell, i. 149. On Dove see his life by Mr. Gordon Goodwin in the Dictionary of National Biography; Calendar State Papers, Dom. 1655, p. 154 ; and Horcurius Politicus, pp. 5196, 6212. As to the proclamation of Charles II at Blandford, see Stato Trials, v. 775. Thurloe, iii. 248, it is statod to have taken place on Tuesday.

* Thurloe, iii. 242, 246, 248, 806.

"Thurloo, iii. 295, 814, 980; English $H$ ist. Reviow, iii. 382.

a Vaughan, i. 151. The 8,000 Somersetshire men mentioned by Thurloe assembled at Taunton, bat their own disputes about the choice of a leader prevented them attacking Wagstaffe's party. Tharloe, iii. 237, 246. 
At Bristol, on the first news of the insurrection, the mayor, aldermen, and common council met together and engaged themselves, by a written declaration, to support ' the Lord Protector, and the Commonwealth under the present government, against Charles Stuart, Cavaliers, Levellers, and all other opposers of the public pease of the nation, and of this city.' ${ }^{33}$ At Gloucester 'the wellaffected ' were put in a posture of defence. ${ }^{\text {s4 }}$ At Exeter, the sheriff, Col. John Coplestone, had some time before received a commission to raise a regiment, and before the Salisbury rising took place he had completed it. It amounted finally to 960 men, of whom four companies were in Exeter. ${ }^{\text {ss }}$ The like preparations were simultaneously being made in other parts of England. ${ }^{56}$ "All the counties in England,' triumphantly concluded Thurloe, 'would, instead of rising for them, have risen against them ; and the Protector could, if there had been need, have drawn into the field, within fourteen days, twenty thousand men besides the standing army. So far are they mistaken who dream that the affections of this people are towards the House of Sturrt.' ${ }^{37}$ In the face of this opposition, and the apathy of their friends, 'the 'lories,' as the Somersetshire men called them, lost heart and hope. From the time they entered Somersetshire their march became a flight. Desertions began, and in their journey from Yeovil to South Molton they lost a hundred men. The one aim of the rest now was to get into Cornwall, to join their friends in that county, and to hold out there. Avoiding Exeter and south Devonshire, they pressed on by Tiverton, Collumpton and north Devonshire, making no stay anywhere. 'They were like a hare started,' says a Cromwellian officer, ' and could not endure the report of any force making towards them, though at a great distance; they were hurried on by their fears and guilt, and hardly stayed three hours in one place.' ${ }^{38}$ It was reported abroad as late as April $\frac{1}{2}$ s that Wagstaffe was in Cornwall with 3,000 men, had broken down the bridges and stood upon his guard.99 Meanwhile the regular troops of the Protector were in hot pursuit. News of the events at Salisbury seems to have reached the Protector on the evening of Monday the 12th. He at once commissioned his brother-in-law, John Disbrowe, to suppress the revolt, appointing him Major-General of the west. "You are to repair with your regiment into the west,' ran his orders, 'and to take into your charge and conduct the troops of Col. Berry now in the west, the two

"2 18 March, 1654; v. Thurloe, iii. 223, 281, 248, 259; Vaughan, i. 152.

"Thurloe, iii. 239.

ss Thurloe, iii. 219 ; Calendar State Papers, Dom. 1655, p. 209.

- Thurloe, iii. 227, 228, 233, 237.

- Vaughan, i. 151. Tharloe to Pell, March 16, written before the news of Wagstafie's defeat came.

4 Calendar State Papers, Dom. 1655, pp. 84, 87, 237 ; Thurloe, iii. 248, 246.

- Egerton MSS. 2595, f. 140. 
troops of Col. Twisleton's whom we have ordered from Chichester to join with you, and also all other forces, both horse and foot, in the western counties.' ${ }^{60}$ Disbrowe, marching by Maidenhead and Reading, had reached Newbury by the night of Wednesday the 14th. ${ }^{61}$ From Newbury he wrote on the morning of the 15th, aaying that he hoped that afternoon to be at Amesbary ' in order to a conjunction with Major Butler, and with the two troops from Chichester,' and then to proceed in pursuit of the cavaliers. ${ }^{62}$.

Major Butler, the commander of the portion of Berry's regiment then in the west, was at Bristol when the insurrection broke out, and could not have received news of the rising till late on Monday the 12th. He left Bristol at once, taking with him the two troops of his regiment stationed there, picked up two other troops which were quartered at Bath, and reached Devizes the same night. ${ }^{63}$ On Tuesday the 19th he marched from Devires to Salisbury, whence on the morning of the 14th he wrote to the Protector announcing his intention of marching at once to Shaftesbury and attacking if he could find an opportunity. 'They were like men that dreamt,' adds Butler, 'to see us so suddenly here.'

Mr. Palgrave sees in Butler's movements one of his most conclusive proofs of Cromwell's complicity in the insurrection. 'Cromwell,' he says, 'deliberately held back Butler against his will.' $\mathrm{He}$ rocaived orders from Cromwell to aroid an engagement, etc., etc. ${ }^{\text {th }}$ In sapport of these definite statements he does not quote Cromwell's orders. There are none to quote. He relies solely upon the letter from Butler to Cromwell, printed in Thurloe iii. 243, and on p. 127 in his last article. 'The tone of this letter,' he argues, 'shows that restraint had been put upon Butler and his plans upset.' $\mathrm{He}$ considers it to be a despairing remonstrance against this restraint. The letter, however, makes no mention of any orders of any kind. It is simply an apology for attacking without orders. "Though I know it would be of sad consequence, if we asseulting them should be worsted, yet I hope your highness will easily pardon me, seeing I shall freely adventure myself upon the good providence of the Lord, who I know will own as; and I am persuaded succeed as in this business.' Nor, whatever Butler's orders may have been, was

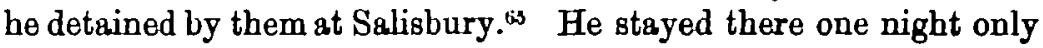
and marched on Wednesday the 14 th to Shaftesbury..$^{\infty}$ At Shaftes-

- Tharlos, iii. 221.

"Thurloe, iii. 247.

- Calendar State Papers, Dom. 1655, p. 80.

" Calendar State Papers, Dom. 1655, p. 80 ; Tharloe, ii. 242.

"English Hist. Rcview, iv. 125-128; Quarterly Review, clxii. 480.

a It is probable that Butler's orders were simply to march on Salisbury and place himsclf ander the command of Disbrowe. See the orlers to Disbrowe given above and the anthorities before referred to.

w 'Thurloe, iii. $238,243$. 
bury, in accordance with the intentions expressed in the postscript to his first letter and in a second letter, he stopped to allow Disbrowe to join him. Disbrowe had overtaken Butler, and they were marching west together when they were met at Wincanton by the news of the defeat of the royalists. ${ }^{67}$ Captain Unton Croke of Berry's regiment, who happened to be quartered at Exeter with his troop, ${ }^{68}$ had attacked them in their quarters at South Molton on the night of Wednesday, $14 \mathrm{March}$, and completely routed them. He gives the following account of his exploit:-

Yesterday morning, being Tuesday, I marched with my troop to Honiton being 15 miles esstward from Exon, with intention to stop the enemy from coming further westward; but gaining intelligence that they were come that way, and that they would be too strong for me, I made my retreat to Exon; the next moming I understood that they were in their march to Cornwall, and in order thereunto they were come to Collumpton, within ten miles of Exon. I heard they were much tired, and their number 200, and therefore imagined that if they should gain Cornwall it might be much prejudicial; I was resolved to hazard all that was dear to me rather than let them have their end, and therefore marched to Collumpton with only my own troop, I had no more for this service; but when I came near that place I nnderstood they were marched to Tiverton, whither I pursued them with speed, but there missed them also; but received information that from thence they were gone to Southmoulton, twelve miles further, still in order for Cornwall; thither I resolved still to follow them.

They took up their quarters about seven of the clock this night, and by the good providence of God, directing and assisting me, $I$ beat up their quarters about ten of the clock; they disputed it very much with me in the houses for more than two hours, firing very hot out of the windows; they shot 7 or 8 of my men, but none were mortally wounded, they shot many of my horse also ; but, my Lord, we broke open many houses; some of them yielded to mercy: I promised them, I would use my endesvours to intercede for their lives. I have taken most of their horses, about 50 prisoners, among whom are Penruddock, Jones, and Grove, who commanded those horse, each of them having a troop. Wagstaff I fear is escaped; he was with them, but at present I cannot find him, yet hope to catch him as soon as daylight appears. I will raise the country to apprehend such stragglers which for want of dragoons narrowly escaped me. My Lord, they are all broken and routed, and I desire the Lord may have the glory. I beseech your highness to pardon this unpolished account. I can hardly indeed write being so worn with extreme duty, but I hope by the next to send your Highness a more perfect one, and a list of the prisoners, many of them, I suppose, being very considerable. Colonel Shapcot of this county was pleased to march with me on this design, and

- Thurloe, iii. 263, 17 March $165 \overline{0}$.

- Thurloe, iii. 165, 219 ; Calendar State Papers, Dom. 1654, p. 585. On the strength of Tharloe, iii. 193, Mr. Palgrave assumes that Crole's troop was stationed at Weymouth. 
was with me at the beating up of their quarters, and has showed himself wonderful ready in every respect, to preserve the peace of the county.

My Lord, I remain, May it plesse your Highness,

Your most obedient and most hamble servant,

UNTON CROKE. 99

From Boathmolton March 15. 1654, about

two or three o'clock in the morning.

With the fight at South Molton the insurrection, which had been so long prepared, from which so much had been hoped, came to an ignominious conclusion. Excepting in the south-west not a blow had been struck or a shot fired. On 24 March the Protector was able to issue circular letters to the militia commissioners and justices in different parts of England announcing the defeat of the insurrection and bidding them be watchful and diligent to arrest alike those who came from abroad to kindle fires in England, and all who could not give a good account of themselves. ${ }^{70}$

If the government had been as well served by its civil officials as it was by its soldiers, the escrpe of the king's agents would have been difficult if not impossible. But the Protectorate was throughout the government of a minority, and the mass of the people were either indifferent or hostile. ${ }^{11}$ Some of the justices themselves were royalists at heart, and more were lukewarm and negligent. Even men who had fought through both wars and sat in the Long Parliament were now so opposed to the government that they were more anxious to screen the royalists than to assist in their arrest. ${ }^{72}$

- Morcurius Politicus, 15-22 Maroh, p. 5204. In a second letter, p. 5206, Croke adds that his own troop was not eixty in number, that there was four hours' dispute in the town, and that he had taken some airty prisoners and 140 horses. Not four men together got away, they were so thoroughly scattered. The enemy was divided into three troops ander Cols. Penraddock, Grove, and Jones respectively. The prisoners he had brought to Exeter, and delivered over to the sheriff. A description of the character of the prisoners is given in Calendar of State Papers, Dom. 1655, pp. 89, 09; a list is in Thurloe, iii. 306. For a life of Croke himself see Sir Alexander Croke's History of the Family of Croke, pp. 625, 547.

10 Calendar of Stats Papers, Dom. 1655, pp. 92, 93; Carlyle, Cromwoll, Appendix, No. 28.

"Clarendon states this very strongly in his narrative of Rochester's expedition. - There cannot be a greater manifestation of the aniversal prejudice and aversion in the whole kingdom towards Cromwell and his government, than that there could be 80 many designs and conspiracies against him which were communicated to so many men, and that such signal and notorious persons could resort to London, and remain there, without any such information or discovery as might enable him to canse them to be apprehended ; there being nobody intent and zeslous to make any such discoveries but such whose trade it was for grest wages to give him those informations; and they seldom care whether what they inform be true or no.'-Rebellion, riv. 180, c. xiii. 110.

7 For instance, it was certified by Rochester's widow at the Reatoration that Col. Hutchinson 'gave the earl of Rochester notice and opportunity to escape when Cromwell's ministers had discovered him the last time he was employed on his Majesty's service here in England.' This refers to this rery expedition.-Seventh Report of Hist. MSS. Comm. p. 120. 
was with me at the beating up of their quarters, and has showed himself wonderful ready in every respect, to preserve the peace of the county.

My Lord, I remain, May it plesse your Highness,

Your most obedient and most hamble servant,

UNTON CROKE. 99

From Boathmolton March 15. 1654, about

two or three o'clock in the morning.

With the fight at South Molton the insurrection, which had been so long prepared, from which so much had been hoped, came to an ignominious conclusion. Excepting in the south-west not a blow had been struck or a shot fired. On 24 March the Protector was able to issue circular letters to the militia commissioners and justices in different parts of England announcing the defeat of the insurrection and bidding them be watchful and diligent to arrest alike those who came from abroad to kindle fires in England, and all who could not give a good account of themselves. ${ }^{70}$

If the government had been as well served by its civil officials as it was by its soldiers, the escrpe of the king's agents would have been difficult if not impossible. But the Protectorate was throughout the government of a minority, and the mass of the people were either indifferent or hostile. ${ }^{11}$ Some of the justices themselves were royalists at heart, and more were lukewarm and negligent. Even men who had fought through both wars and sat in the Long Parliament were now so opposed to the government that they were more anxious to screen the royalists than to assist in their arrest. ${ }^{72}$

- Morcurius Politicus, 15-22 Maroh, p. 5204. In a second letter, p. 5206, Croke adds that his own troop was not eixty in number, that there was four hours' dispute in the town, and that he had taken some airty prisoners and 140 horses. Not four men together got away, they were so thoroughly scattered. The enemy was divided into three troops ander Cols. Penraddock, Grove, and Jones respectively. The prisoners he had brought to Exeter, and delivered over to the sheriff. A description of the character of the prisoners is given in Calendar of State Papers, Dom. 1655, pp. 89, 09; a list is in Thurloe, iii. 306. For a life of Croke himself see Sir Alexander Croke's History of the Family of Croke, pp. 625, 547.

10 Calendar of Stats Papers, Dom. 1655, pp. 92, 93; Carlyle, Cromwoll, Appendix, No. 28.

"Clarendon states this very strongly in his narrative of Rochester's expedition. - There cannot be a greater manifestation of the aniversal prejudice and aversion in the whole kingdom towards Cromwell and his government, than that there could be 80 many designs and conspiracies against him which were communicated to so many men, and that such signal and notorious persons could resort to London, and remain there, without any such information or discovery as might enable him to canse them to be apprehended ; there being nobody intent and zeslous to make any such discoveries but such whose trade it was for grest wages to give him those informations; and they seldom care whether what they inform be true or no.'-Rebellion, riv. 180, c. xiii. 110.

7 For instance, it was certified by Rochester's widow at the Reatoration that Col. Hutchinson 'gave the earl of Rochester notice and opportunity to escape when Cromwell's ministers had discovered him the last time he was employed on his Majesty's service here in England.' This refers to this rery expedition.-Seventh Report of Hist. MSS. Comm. p. 120. 
In addition to this the existing police system was extremely inefficient. The parish constables and the town watchmen were still of the type described by Shakespeare, and as little likely to arrest a desperate cavalier as Dogberry's men were to stop any one who declined to stand..$^{\text {t3 }}$ This was one of the chief reasons for the appointment of the major-generals, whose instructions show that their troopers were meant to be a military police, rather than a militia in the ordinary sense of the word. ${ }^{71}$ These causes, and not any supposed slowness in Cromwell to arrest them, made it possible for the royalists to escape the pursait of the government. . Once out of the hands of the soldiers it was easy for a cavalier to get clear away. Two of the Yorkshire plotters, Sir Richard Mauleverer and Mr. Walters, were arrested at Chester but escaped from custody and made their way safely to Flanders. ${ }^{73}$ Mr. Eyton, one of the most trusted associates of Sir Thomas Harris, broke prison at Shrewsbury and got clear off. ${ }^{76}$ More remarkable was the escape of Major Thomas Hunt, one of the Salisbury insurgents. He lay in Ilchester gaol condemned to death, but the night before the day fixed for his execution his two sisters, Elizabeth and Margery, obtained leave to visit him. He changed clothes with Margery, succeeded in passing his guards, and finally reached the continent in safety. ${ }^{77}$ Of Wagstaffe's escape little is known. Clarendon says vaguely that he and some others 'found shelter in some honest houses, where they were concealed till opportunity served to transport them into the parts beyond the seas.' 78 It is possible to follow Rochester's movements a little more closely. After the dispersion of the gathering on Marston Moor he mode his way ' through byroads to London, which was the securest place.' Clarendon adds that 'if he had not been a man very fortunate in disguises, he could never have escaped so many perambulations; for as he was the least wary in making his journeys in safe hours, so he departed very unwillingly from all places where there was good eating and drinking, and entered into conferences with any strangers he met or joined with.' ${ }^{79}$ Sometimes he would go disguised as a Frenchman,

$n$ 'This is your charge :-you shall comprehend all vagrom men; you are to bid any man stand in the prince's name.

' How, if a' will not stand?

- Why, then, take no note of bim, bat let him go; and presently call the rest of the watch together and thank God you are rid of a knave.'

Much Ado about Nothing, iii. 8:

"Old Parliamontary History, xx. 461-7, clauses 3 to 20 inclugive.

"Thurloo, iii. 278, $304 . \quad$ ib. iii. B37, 706.

is Thurloe, iii. 458; Metcurius Politicus, May 17-24, p. 5856. Thomas Hunt was an ancestor of Henry Hunt the radical, who during his imprisonment in the same gaol wrote an account of his own life in which he gives a detailed narrative of the escape of his relstive. The sisters suffered two years' imprisonment.-Memoirs of Henry Hunt, 1820, i. pp. 22-88. Severth Report of Hist. MSS. Comm. p. 123.

Thebllion, xir. 184 .

Ib. xir. 185 . 
and wearing a jellow periwig, sometimes 'like a grazier with a brave basket-hilted sword tied up to his back.' ${ }^{80}$ At Aylesbury he had a narrow escape. A county justice having examined Rochester and his companions ordered the innkeeper with whom they lodged to detain them till the following day, when Col. Ingoldsby, the officer in charge of the district, was expected. Rochester bribed the innkeeper with his gold chain, and fled during the night in compeny with Nicholes Armorer, leaving behind him his luggage and his two servants. This took place on $20 \mathrm{March}$, but the negligent justice did not report the incident to the Protector till 2 april..$^{81}$ When Wilmot's French servant arrived in London (6 April) it was speedily discovered whom he served. An account of Rochester's escape was published in the newspapers, and orders were sent to search all ships for him and other cavaliers. ${ }^{82}$ For some time Rochester soems to have hidden himself in London, where concealment was easier than in the country. Manning the spy repeatedly wrote to Thurloe, telling him (' q, near as I can guess') where Wilmot and other persons were to be fonnd, naming especially the Savoy, Covent Garden, and some taverns in Drury Lane. ${ }^{\text {ss }}$ Searches were made in different parts of the city, and a number of persons, including Sir Thomas Armstrong and Abraham Cowley, were arrested.s On the night of 21 May there was a great search about Covent Garden, but though Lord Byron and other cavaliers were taken there, Rochester was not to be found. At the end of May and the beginning of June scores of gentlemen were seized, and finally on 6 July all who had ever served the king were ordered to leave London before the 12th. ${ }^{\text {ss }}$ By this time, however, the king's chief agents had escaped. O'Neill reached the Hague at the beginning of May, Rochester and Armorer early in June, followed somewhat later by Wagetaffe. ${ }^{80}$

Meanwhile the trial $\}_{r}$ of those who had taken part in the rising

- Thurloe, iii. 889 ; Egerton MSS. 2585, t. 289.

1 Thurloe, iii. 281, 385 ; Clarendon, xiv. 186.

- Horc. Politicus, 6-12 April, p. 5259; Porfect Proceedings, 9 April; Cal. Stato Papers, Dom. 1655, p. 127; Thurloe, iii. 352, 356.

"Thurloe, iii. B54, 358, 429. "Mercurius Politicus, ander 12 April.

"Cal. State Papers, Dom. 1655, p. 232. Newspapers, passim.

s. Thurloo, iii. 409; Egetton AfSS. 2585, ff. 278, 281. Rochester was in England a little over three months, from ahout 20 Feb. 0.S., to about $10 \mathrm{Jane}, \mathrm{O} . \mathrm{S}$.; he is mentioned by Jane as being beck at Brussels in s letter of 41 June. Armorer embarked at Gravesend, Egorton MSS. 2535, fo. 281 ; Rochester sailed according to one account from the const of Essex according to anotber from Yarmouth, Thurloe, iv. 101, Cal. State Papers, Dom. 1e55, p. 215; on Wagstaffe, ibid. p. 846. Mr. Palgrave's theory is that the royalist leaders escaped because Cromwell connived at their doing bu. Cromwell, he ssys, was prevented from arresting them by his contract with Willis; he states that Hochester and his associates stayed in England tive monthe, and assumes that they all returned by way of Dover. (Quarterly Reviow, clrii. pp. 429, 425, 445; Ehg. Hist. Rev. iv. 129-4.) His evidence for these statements I have not succoeded in discovering; the contract with Willis I shall discuss leter. 
was proceeding. Two commissions of Oyer and Terminer wert issued, one for the trial of the western prisoners, another for that of the northern. ${ }^{87}$ The commissioners sat at Salisbury on 11 April, at Exeter on 18 April, and at Chard on 25 April. 'This is the first time,' wrote Thurloe to Pell, ' that treasons against the government have been submitted to juries since the year 1646, and we do not doubt, but to have good issue of it.' ${ }^{\text {s }}$ But the sheriffs were forced to exercise considerable care in the choice of juries, as honest jurymen, that is, men who believed it to be treason to levy war against the Protector, were in a decided minority. ${ }^{89}$ At Salisbury six persons were found guilty of treason in levying war, one confessed, and three were acquitted. Six were found guilty of felonies, such as breaking gaol and horse-stealing. Witnesses were found by allowing the underlings to turn evidence against their leaders. 'We did not think fit to try them all,' writes Thurloe, 'pona ad pancos, metus al omnes. The jury found them guilty as readily as if they had been thieves or robbers; '90 of the condemned two were hanged at Salisbury on 8 May, viz.: Thorp a cloth worker, and Kensey a surgeon ; a third, John Lucas, being a man of some position, was beheaded.91

At Salisbury Windbam had been the chief manager of the trial, at Exeter it was Glyn's turn. This was the most important of the three sittings of the commissioners, for the leaders of the rebellion were to be tried there. Thirty persons in all were indicted of high treason, of whom twenty-six were condemned, including five who confessed and pleaded guilty. Three were acquitted by the petty jury, and in one case the grand jury returned an ignoramus. Of these thirty, eighteen are described as gentlemen, and four as yeomen; there were also twu innkeepers, a labourer, a cordwainer, a cutler, and a trumpeter. ${ }^{92}$

Penruddock's defence consisted in an argument that his offence was not legally high treason, and in the claim that he had surrendered on articles promising security for life and estate. ${ }^{93}$ But

"Cat. Stato Papers, Dom. 1655, pp. 90, 106, 112, 114.

- Vaughan, i. 163 ; cl. Clarendon, Reballion, ziv. 35.

- Cal. State Papers, 1655, p. 120 ; Thurloe, iii. $818 . \quad$ ovaughan, i. 167.

"I Mercurius Politicus, 12-19 April, p. 5275; ibid. 8-10 May, 5323. The Trial of Mr. Mack, etc., King's Pamphlets, E. 833. (8) ; Perfect Proceedings, 3-10 May; Faithful Scout, 4-11 Mey. See also Thurloe, iii. 361-381, passim. The indictment is given in Tharloe, iii. $\mathbf{9 7 0 .}$

"Thurloe, iii. 894. An account of the trial, written either by Penruddock or one of his friends in his name, is reprinted in State Trials, vol. v. Soe also Thurloe, iii. 882, B91, 394, 398, 442.

" Croke denied making sny such conditions. He admitted having promised some that he would intercede for their lives, and in two letters to the Protector did intercede tor the lives of 5 men 'the most inconsiderable of the company' who had rept a house against him for four hours ('Tharloe, iii. 281, 368). But he denied the articles claimed by Penruddock. Penruddack in his dying speech stated that the articles were drawn by his (Penraddock's) own hand, and added: 'Thus much I am obliged to say 
the court naturally declined to entertain a plea which amounted to a denial of its own jurisdiction, and the second statement was not sufficiently proved to be accepted. Of the persons condemned fourteen were hanged at Exeter on 7 May, seven for treason and seven for felonies. Of the leaders, two Colonels, Penruddock and Grove, were beheaded, nnd a third, Colonel Francis Jones, pardoned. Hugh Grove and John Penruddock were both beheaded on 16 May.94

The last meeting of the commissioners took place at Chard on 25 April. There proceedings were less simple, for most of the prisoners consisted of stragglers, who had not been actually taken in arms. Five or six, however, were condemned to death, inclading Captain Thomas Hunt, but Major Clark, son of Sir Edward Clark, was acquitted. How many were actually executed there seems to be no evidence to determine. Thurlne, summing up the general result of the trials, wrote to Pell saying that thirty-nine had been condemned as traitors. 'Some of them his highness has reprieved, his course being to use lenity, rather then severity. About fourteen or fifteen will be executed and no more.' 95

Meanwhile the commission which was to sit in the northern counties had not yet begun its work. It was to have met at York about 20 April, but unexpected obstacles arose. In the first place, since the conspirators had not been taken in arms, evidence other than that of persons themselves engaged in the design was difficult to procure. But, as Solicitor-General Ellys wrote to Thurloe: 'The testimony in this case ought to be very clear and evident of the plot, design, and intention of those men; else a jury will be hardly persuaded, that meeting together, though in such a manner as they did, and going away without effecting more, is high treason.' 96 In addition to this the three chief commissioners, Judges Thorpe and Newdigate and Serjeant Hutton, doubted

to the honour of the soldiery, that they have been so far trom breaking any articles given to others, that they have rather bettered them than otherwise. . . . I will not do the Proteotor so much injary as to load him with dishonour, since I have been informed that he would have made our conditions good if Crook, that gave them, had not abjured them.'-State Trials, $\nabla .779$. Evidence is wanting to decide which of these two acoounts is true.

o The speeches of Grove and Penruddock are printed in England's Black Triburat, 1660, p. 175, and in Ixacke's Antiquitios of the City of Exetor, 1677, pp. 10-10. The latter work also contains a letter from the condemned prisoners to their judges asking them to intereede with the Protector for their lives (p. 163). The night before his death Penraddock wrote a beatiful and touching letter to his wife, which is printed in the contemporary acoount of his trial, and in Stats Trials (v. 789). Steele quotes it with admiration and sympathy in 'The Lover,' No. 8. The original of this letter and other relice of John Penruddock are still preserved at Compton Chamberlain by his descendant Col. Charles Penruddock. (Hosre, Modern Wutshire, 'Dunworth,' p. 84.)

a Vaughan, i. 172. On the procedings at Chard there is very little information sccessible. Bee Thurlos, iii. 407 ; Mercuritu Politicus, p. 5808; Porfoct Accourt, 2-9 May, 1655.

- Cal. Stato Papers, Dom. 1655 Fp. 106, 116, 117 ; Thurloe, iii. B74. 
whether in point of law the actions of the prisoners amounted to treason, and accordingly the two former received their writ of ease from the Protector on 3 May. ${ }^{97}$ In consequence of these difficulties the intended commission seems to have been abandoned. 'The imprisoned gentlemen in the north,' wrote Nicholas to Jane in the following September, 'are only fined by the judges for riots and misdemeanours, and released on bail.' 98 Many of them, however, were subsequently severely mulcted by the major-generals of their respective districts for their share in the conspiracy, and Sir Henry Slingsby appears to have been retained in prison..$^{99}$

The last question to be decided was the punishment of the less important prisoners and of those who had been reprieved by the Protector. In 'Mercurius Politicus' for 24-31 May 1655, it was announced that 'divers persons, prisoners in the Tower, who were in the last year's conspiracy against his highness' person, and most of those in the grols in the west, who were in the late rebellious insurrection, were to be sent away to the foreign plantations.' 'This was a method of treating criminals of all kinds much in favour during the seventeenth century. Condemned felons and vagrants were from the time of James I frequently sent to serve for a fixed space of time in the American or West Indian colonies. ${ }^{100}$ The Long Parliament applied a similar treatment to prisoners taken in war. Some hundreds of Scots were sent to the West Indies after Dunbar and Worcester, and after the conquest of Ireland a similar fate befell some thousands of Irish. ${ }^{01}$ Succeeding governments adopted the same expedient. After the suppression of the rising in Scotland in 1666 a number of the rebels were sentenced to transportation; 841 persons who had taken part in Monmouth's insurrection, and 638 of the Jacobite prisoners of 1715 . were similarly punished. ${ }^{102}$ There was therefore nothing exception-

nTarloe, iii. 859, 885; More. Politicus, 8-10 May, p. 5823. I can find no anthority for the oircumstantial story told by Foss in his life of Newdigate.

- Calendar State Papers, Dom. 1655, p. 825.

- The Perfect Diurnal, 7-14 May, p. 4856, mentions the condemnation of seven persons at Morpeth. In Perfoct Proceedings, 10-17 May, pp. 4663-5, it is stated that twenty persons in all were tried, released, or imprigoned for the late plot. But while the Faithful Scout, 11-18 May, describes the seven persons executed as martyrs for the king's cause, Perfoct Proceedings states that they suffered for sheepstealing. I believe that the latter is correct, and that no one was capitally panished in the north for this conspiracy.

160 Doyle, English in America, i. 511 ; Calerdar State Yapers, Col. 1661-8, p. 29 ; Dom. 1655, pp. 107, 329 ; ibid. 1655-6, pp. 208, $265,301$.

101 Bisset, Commontoealth of England, i. 383, i. 204 ; Prendergast, Cromwellian Sethlement of Irehard, ed. 2, pp. 88-93.

is Burton, History of Scotland, vii. 176; Catendar Slate Papers, Col. 1061-8, p. 492; Macaulay, History of England, ii. 230; A Faithful Register of tho lato Rebellion, 1718, p. 408. The sufferings of those transported for Monmonth's rebellion are related in the narratives of John Coad and Henry Pitman. Defoe allades to the exiled Jacobites in his Life of Colonel Jack, p. 342, ed. 1734. 
ally cruel in the punishment inflicted by the Protector on the prisoners for the western rising, harsh and arbitrary though it undoubtedly was. On 18 May 1655, a warrant was issued for the transportation to Barbadoes of eight persons, then prisoners in the Tower, most of them persons who had been concerned in Gerard's plot. $^{103}$ On 30 Nov. following, it was further ordered that the persons still in prison, for the Salisbury rising, at Exeter and other places in the west, should also be sent to the same place. The number of persons thus transported appears to have been seventy. ${ }^{104}$

But the penal consequences of the insurrection did not end with the punishment of those actually taken in arms. It had obliged the government to raise extra forces, and it was deemed necessary for the security of the public peace to continue to maintain a portion of those forces. In May 1655, it was decided to reduce the regular army and to establish a militia in every county to repress any attempts at rebellion, and to enforce the police regulations of the government. This militia consisted of one or two troops of horse in each county, was to be paid on a very liberal scale, and must have involved an additional expenditure of between forty and sixty thousand pounds per annum. In some counties there were two troops, in others one; sometimes the troop numbered sixty, sometimes a hundred. The scale of pay is given in 'Mercurius Politicus,' p. 5872. I can find no statement of the total cost. ${ }^{105}$

It was resolved to raise this sum from the estates of the cavaliers. In a declaration published at the beginning of November 1655, the Protector gave a narrative of the late conspiracy and insurrection, explained the necessity of establishing this militia, and justified the resolution to put the cost of it on the cavalier party. Only a small portion of their number had taken part in the Salisbury rising, but all were concerned in the plot:-

It may perhaps be esteemed grent severity, to tax the whole party, when there hath been, in respect of the general number, but few convicted by trial, or detected by testimonies to have been in those designs. . . . But we do appesl to all indifferent men, who will weigh and consider the preceding narrative, and the contesture, frame and circumstances of this design, whether the party were not generally involved in this business and in reason to be charged with it. ${ }^{106}$

16] Thurloe, iii. 453. Two of the eight were not transported; ibid. vii. 689.

104 Calendar State Papers, Dom. 1655-6, p. 42. The petition of these persons to the parliament of 1659 , and the debate which took place on it are to be fonnd in Burton's Diary, iv, 255. Of these persons some had been condemned and reprieved, but many had never been tried by any legal cont. In the case of one at leant, vis. Marcellus Rivers, the grand jury at Exeter had returned an ignoramus, but he was nevertheless transported (Tharloe, i. 745, iii. 898).

we Calendar State Papers, Dom. 1655, pp. 77, 267, 896.

we A Declaration of his Highness by ths Advice of his Council, shewing the Reasons of their Procedings for sceuring the Peace of the Commonwealth, upon Occasion of the late Insurrection and Rebellion, 1655, p. 34. 
That the conspiracy was far wider and more general than the feebleness of the actual attempts at insurrection would seem to show, the correspondence of the conspirators themselves proves. A royalist contemporary remarks :-

All the gentlemen in England of that party were one way or other engaged, or at least were made acquainted with it, but the snatching of the principal of them ap thronghout the kingdom, a little before the execution of it, frustrated the most probable effects of that rising. ${ }^{107}$

The causes of the failure of this long-prepared design are best explained by the royalists themselves. Clarendon blames the active section of the English royalists for their exaggerated promises and their erroneous estimate of their own strength, and attributes much importance to the dissensions which existed between them and the more cautious section of the party. He also blames the king's agents, the mistakes of the leaders of the Salisbury insurgents, and the mismanagement of Rochester. Throughout his whole narrative he soeks as far as possible to clear the king and his. advisers of responsibility, and to vindicate their policy. ${ }^{108}$

At the time many blamed Hyde himself. Captain Peter Mews (afterwards Bishop of Winchester) wrote thus to Nicholas :-

You would hardly credit how severely the miscarriage of the business reflects apon Sir Edward Hyde, for being by most supposed to be, if not the sole, yet the chief manager of this design, the whole weight lies upon him, and though something in general may fall upon his majesty, yet the hottest charge is upon him ; and it is not here talked in corners that if Sir Edward Herbert and Lord Jermyn had been interested in the design the miscarriage would have been laid at their door. ${ }^{109}$

The repeated postponement of the time of action was recognised as one of the chief causes of failore. One of Thurloe's agents writes on 15 July :-

Mr. Armorer and Sir Joseph Wagstaffe, newly arrived from England, say there are yet many of Charles Stuart's friends who would show them. selves in another design, though the last had no better success. The reason was the King kept not the day promised for their rising, bat broke twice with them, which made many think they were fooled, and so they never appeared. They say the people are well affected to Charles Stuart, but their own factions at court are the ruin of every plot." ${ }^{\text {"10 }}$

In addition to the factions at court there were the dissensions amongst the English royalists which Clarendon mentions.

I find by disconrse with Colonel Mor san [writes Mews] that there were very great divisions in the councils of those who were employed in England

${ }^{107}$ Heath, Chronicle, p. 678, ed. 1668. Mr. Palgrave quotes Heath as a valuable anthority, both as to the facts of the rising and as to Cromwell's character, Eng. lish Hist. Review, iv. 130. Qtuarterly Reviow, clxii. 431.

10: Rebellion, riv. 128-147.

$10 *$ Egerton MSS. 2535, 1. 147.

11. Calendar State Papers, Dom. 1655, p. 245. 
for his Majesty. Those of the west and Kent agreed well enough, but the north and they differed." 11

The dangers of postponement and the evils of division were increased by the imprudence of the conspirators. Several weeks before the rising took place Joseph Jane wrote to Nicholas saying :-

It's extraordinary if some ill accident come not, considering the letters that bave been for divers weeks written from England, and the talk here I presume must be known to the rebels. ${ }^{118}$

Captain Mews writing on 23 April takes exactly the same viow.

It was indeed very strange to me to find the business so publicly discoursed of here, before my going into Scotland (January, 1655), there being scarce a lackey or serving-man or woman which could not say more by much than I knew; for indeed I knew nothing but in general that his majesty was resolved to try his friends, which he himself told me, but here every one would descend to particulars which I must confess gave me no small argument of fear, for the place never wants those who will sapply the rebels with intelligence. ${ }^{213}$

In a letter written by Joseph Jane tc Nicholas on 4 May, 1655, he makes the following general reflections on the consequences and causes of the great failure :-

I muat acknowledge my hopes much fallen touching our affairs, but I ever relied on God's mercy, and in my expectations thought our restitution would be as strange as onr confusion, and truly, though I was ready to entbrace hipes upon so probable designs, yet I had still some relactances of belicf, and I am still of opinion as before that whenever it comes it will be near a miracle, though just right, against an usurper and one as odions for his villanies and disposition es his treason, might givo great cause of hopes, that the people would not be long kept off from their own deliverance, but all this is in God's hands who gives spirits to a people and provides means to work upon, and we find from the temper of the people small grounds of confidence, and there are a great number that look not on the way where they missed, and whereby they must return, if ever, but dream of new models in state and free, that is absolute, parliaments, aud the means to keep them free and right, and besides this among ourselves the factious animosities and vicious habits are no good signs of men prepared for a deliverance. ${ }^{114}$

C. H. Firth.

(To be continued.)

LETTERS OF THE REV. WLLLLAI AYERST, 1706-1721 (continued). Communicated by C. E. Dorks.

22. W. Ayerst to Dr. A. Charlett.

'Berlin, Sep" 224 708 N.8.

- 'Hond Sir-'Tis my Misfortune of late not to receive Your favoura till long after their Date, We went on board $y^{\circ}$ Day You were pleas'd to write, after 3 weeks laying in $y^{\circ}$ Yacht I met your

il Egerton MSS. 2585, f. 299.

11 Egerton AfSS. 2535, f. 12, 5 Jan. 1655.

114 Egerton MSSS. 2535, 1. 161. 